\title{
SOSIALISASI EMPAT PILAR KEBANGSAAN HUMAS MPR RI MELALUI KEGIATAN SOSIAL BUDAYA
}

\author{
Rialdo RM.L.Toruan, Radja Erland Hamzah, Aida Permata Sari \\ Email: rialdo.rezeky@gmail.com \\ Fakultas Ilmu Komunikasi Univ. Prof. Dr. Moestopo (Beragama)
}

\begin{abstract}
ABSTRAK
Penelitian ini bertujuan untuk mengetahui bagaimana sosialisasi empat pilar kebangsaan oleh Humas MPR RI melalui sosial budaya. Konsep yang digunakan dalam penelitian ini adalah Hubungan Masyarakat dan Model Four Steps Cultip, Center \& Broom. Jenis penelitian ini adalah kualitatif deskriptif, teknik pengumpulan data yang dilakukan untuk memperoleh data ialah wawancara dan observasi. Paradigma penelitian ini menggunakan konstruktivisme dan metode studi kasus. Hasil penelitian ini menunjukan bahwa Humas MPR RI dalam melaksanakan sosialisasi empat pilar kebangsaan dengan mengemas unsur-unsur dan nilai melalui seni budaya yang disesuaikan dengan kondisi lokal sehingga mampu mengangkat kearifan lokal dan warisan para leluhur yang sejalan dengan falsafah hidup bangsa Indonesia.
\end{abstract}

Kata Kunci: sosialisasi, empat pilar kebangsaan, hubungan masyarakat, model four steps

\begin{abstract}
This study aims to find out how the socialization of the four pillars of nationalism by the People's Consultative Assembly of the Republic of Indonesia through social culture. The concepts used in this study are Public Relations and the Four Steps Model Cultip, Center \& Broom. This type of research is descriptive qualitative, data collection techniques used to obtain data are interviews and observation. This research paradigm uses constructivism and case study methods. The results of this study indicate that the MPR RI Public Relations in carrying out the socialization of the four pillars of nationalism by packaging the elements and values through cultural arts that are adapted to local conditions so as to be able to lift local wisdom and heritage of the ancestors in line with the philosophy of life of the Indonesian people.
\end{abstract}

Key Words: socialization, four pillars of nationality, public relations, the four steps model

\section{PENDAHULUAN}

Public Relations di Indonesia menggunakan istilah Hubungan Masyarakat disingkat Humas. Dalam organisasi atau lembaga baik pemerintah maupun swasta terdapat Biro Hubungan Masyarakat, Bagian Humas Masyarakat atau Divisi Hubungan Masyarakat yang kepentingan dan posisinya sangat tergantung dari besar atau kecilnya lingkup pekerjaannya. Organisasi atau lembaga dalam menjalankan aktivitasnya selalu berhubungan dan berkaitan dengan publik, baik dalam pengertian sempit maupun secara luas. Kehadiran Humas ini dalam sebuah organisasi atau lembaga sangat penting, hal ini terkait dari aktivitas organisasi atau lembaga dengan publik, maka perlu adanya jembatan untuk membangun komunikasi yang baik dan terarah. Maka harus ada pihak yang melakukan yaitu kerja-kerja Humas atau Public Relations. Pengertian Humas atau PR (Public Relations) adalah suatu usaha yang sengaja (Saefullah dan Rialdo, 2017: 79-105)

Oleh karena itu mengapa posisi humas dianggap sangat penting dalam sebuah organisasi atau perusahaan, seperti yang dikatakan oleh Dr. Rex F Harlow yang merupakan ilmuan dan tokoh profesional humas mengatakan:

"Humas merupakan fungsi manajemen khusus yang membantu pembentukan dan pemeliharaan garis komunikasi dua arah,saling pengertian, penerimaan, dan kerja sama antar organisasi dan 
masyarakatnya, yang mellibatkan manajemen problem atau masalah,membantu manajemen untuk selalu mendapat informasi dan merespon pendapat umum,mendefinisikan dan menekankan tanggung jawab manajemen dalam melayani kepentingan masyarakat. Membantu manajemen mengikuti dan memanfaatkan perubahan dengan efektif. Berfungsi sebagai system peringatan awal untuk membantu mengantisipasi kecenderungan dan menggunakan riset serta komunikasi yang masuk akal dan etis sebagai sarana utamanya“"

Sosialisasi Empat Pilar Kebangsaan menjadi salah satu agenda rutin dari Majelis Permusyawaratan Rakyat (MPR) Republik Indonesia (RI) yang selanjutnya dalam penelitian ini disebut MPR RI. Ke empat pilar tersebut yaitu Pancasila, UUD 1945, NKRI dan Bhinneka Tunggal Ika sebagai konsep pokok dalam kehidupan berbangsa dan bernegara. Dalam tatanan berbangsa bernegara perlu diperkuat dengan pilar-pilar sehingga kokoh. Empat pilar adalah penyangga yang kokoh bagi bangsa sehingg rakyat bisa hidup damai, aman dan bersatu membangun bangsa dalam suasana demokratis (Sekjen MPR RI Ma'ruf Cahyono, Dalam Sambutan Sosialisasi Empat Pilar, Oktober 2019)

Lebih lanjut Ma'ruf Cahyono mengatakan Pancasila, UUD 1945, NKRI dan Bhinneka Tunggal Ika sebagai empat pilar kehidupan berbangsa dan bernegara mengajarkan bangsa ini hidup dalam suasana gotong royong, rukun dan saling toleran. Melestarikan nilai-nilai luhur yang hidup dalam masyarakat merupakan bagian yang menyatu dengan semangat Pancasila sebagai falsafah Negara. Maka sosialisasi empat pilar kebangsaan akan terus dilakukan dengan berbagai metode sehingga mudah dan sesuai dengan nilainilai yang dianut masyrakat serta hidup sesuai nilai sosial masyarakat Indonesia.

Dalam penelitian ini MPR RI melakukan sosialisasi dengan metode atau cara yang lebih kultural yang disesuaikan dengan budaya setempat. Di Jawa sosialiasasi dilakukan dengan pagelaran wayang dengan maksud untuk merawat kearifan lokal. Di Sumatera, juga berbeda, di Sumatera Utara misalnya dengan tari Tor-Tor, di daerah yang sukunya melayu menggunakan pantun, sampai ke Indonesia bagian Timur. Sebagaimana dikatakan Kepala Biro Humas MPR RI Siti Fauziah dalam sosialisasi empat pilar kebangsaan menggunakan metode sosial budaya karena dalam seni budaya kita (nasional) terkandung nilai filosofis berisi tuntunan dan panutan dan tuntunan selain sebagai hiburan (wawancara dengan peneliti Oktober 2019).

\section{LITERATUR DAN METODOLOGI Hubungan Masyarakat (Public Relations) \\ Cultip-Center-Broom dalam buku} Effective Public Relations (2011) mendefenisikan Humas sebagai the planned effort to influence opinion through good character and responsible performance, based on mutually satisfactory two way communications (usaha terencana untuk mempengaruhi pandangan melalui karakter yang baik serta tindakan yang bertanggung jawab, didasarkan atas komunikasi dua arah yang saling memuaskan).

Lebih lanjut Frank Jefkins memberi batasan Humas, yaitu "sesuatu yang merangkum keseluruhan komunikasi yang terencana, baik itu ke dalam maupun ke luar antara suatu organisasi dengan semua khalayaknya dalam rangka mencapai tujuan-tujuan spesifik yang berlandaskan pada salin pengertian (Morissan, 2006:8).

Salah satu fungsi PR adalah menjalin komunikasi dan relasi dengan publik-publik organisasi. Dampak dari terwujudnya fungsi ini adalah pencapaian tujuan organisasi. Tujuan organisasi itu dibantu pencapaiannya melalui kegiatan PR dengan meningkatkan, menjaga atau memperbaiki prestise organisasi, 
mendeteksi dan menangani isu-isu yang berkembang, dan mengatasi kesalahpahaman dan parasangka (Iriantara, 2006:5).

Dari defenisi tersebut dapat dijelaskan bahwa para praktisi humas harus dengan baik membuat perencanaan yang baik dan mengenal khalayaknya dengan baik kemudian mampu menentukan cara atau motede yang tepat dalam komunikasinya sehingga tujuan dari pesan yang disampaikan dapat diterima dengan baik oleh pihak pemberi dan penerima pesan. Perencanaan dan moetode menjadi kata kunci bagi Humas dalam menjalankan program-programnya sehingg mempunyai dampak bagi khalayak.

\section{Strategi Humas/Public Relations}

Kata strategi mempunyai pengertian yang terkait dengan hal-hal seperti kemenangan atau daya juang. Artinya menyangkut dengan hal-hal yang berkaitan dengan maupun atau tidaknya perusahaan atau organisasi menghadapi tekanan yang muncul dari dalam atau dari luar. Strategi dapat diartikan sebagai keterampilan manajerial (administrasi. Kepemimpinan dan kekuasaan).

Strategi menghasilkan gagasan dan konsepsi yang dikembangkan oleh organisasi atau praktisi. Strategi menyangkut perencanaan, sumber daya komunikasi yang tersedia untuk mencapai tujuan yang ditetapkan. Sebagaimana (Ruslan, 2008:31) menyebutkan strategi pada hakekatnya adalah suatu perencanaan (planning) dan manajemen (management) untuk mencapai tujuan tertentu dalam praktik operasionalnya. Pandangan lain mengemukakan bahwa strategi merupakan model perencanaan yang secara eksplisit dikembangkan oleh para manajer dengan mengidentifikasikan arah tujuan, kemudian mengembangkan rencana tersebut secara sistematis dan terukur untuk mencapai tujuan.
Defenisi yang lain tentang strategi oleh Robbins dalam Erlina Hasan (2005:43) sebagai penentuan tujuan jangka panjang perusahaan dan memutuskan arah tindakan serta mendapatkan sumber-sumber yang diperlukan untuk mencapai tujuan.

Rogers (1982) memberi batasan pengertian strategi komunikasi sebagai suatu rancangan yang dibuat untuk mengubah tingkah laku manusia dalam skala yang lebih besar melalui transfer ide-ide baru (Canggara, 2017:64).

Dalam strategi komunikasi kombinasi dari peranan komunikator, pesan, media, saluran, penerima dan efek harus dirancang dengan baik dan tepat sehingga tujuan komunikasi dapat dicapai dengan baik. Pemilihan strategi merupakan langkah krusial yang memerlukan perhatian dan keterpaduan para pelaksana/praktisi dalam merencanakan komunikasi sebab ketika perencanaan salah maka tujuan komunikasi juga salah bakal berakibat fatal.

\section{Sosialisasi}

Sosialisasi merupakan proses belajar mengajar mengenai pola-pola tindakan interaksi dalam masyarakat sesuai dengan peran dan status social yang dijalankan masing-masing. Dengan proses itu, individu akan mengetahui dan menjalankan hak dan kewajibannya berdasarkan peran status masing-masing dan kebudayaan suatu masyarakat. Dengan begitu, jelaslah bahwa sosialisasi adalah proses berbaur, mencari tahu, member tahu dan interaksi antara satu orang dengan orang lainnya.

Dalam bersosialisasi, kita harus memperhatikan lingkungan social. Lingkungan social adalah lingkungan masyarakat yang di dalamnya terdapat interaksi antara individu dengan individu yang lain. Yang terlibat dari proses sosialisasi tersebut adalah manusia sebagai mahluk social, yang berhubungan dengan sekitarnya, serta adanya dorongan untuk mengabdi kepada masyarakat. 
Dalam buku Pengantar Sosiologi Robert Lawang (2004) membagi sosialisasi menjadi dua macam, yaitu:

Sosialisasi Primer, proses ini dimulai dengan mengakumulasi pengetahuan dan keterampilan yang diperlukan untuk menjadi anggota dalam masyarakat tertentu. Proses ini melibatkan berbagai aktivitas seperti bermain, meniru mengamati dan dalam interaksi dengan aktor penting sosialisasi; orang yang berpengaruh adalah orang tua, teman sebaya dan saudara kandung.

Sosialisasi Sekunder, terdiri atas pengalaman-pengalaman yang kompleks dan terjadi sepanjang masa untuk menjadi anggota masyarakat atau kelompok budaya tertentu. Sosialisasi sekunder merupakan proses memahami dan merasakan berbagai budaya yang ditunjukan dalam kehidupan secara keseluruhan.

Seperti yang telah dipaparkan diatas, sosialisasi memiliki banyak persepsi yang berbeda-beda sehingga penulis dapat menarik kesimpulan bahwa sosialisasi berarti proses belajar seseorang untuk mempelajari norma dan nilai kebudayaan masyarakat dalam lingkungannya. Namun, sosialisasi dalam penelitian ini lebih menekankan pada bagaimana seorang public relations dapat memberikan dan menyebarkan informasi tentang suatu produk, program dan halhal yang memiliki nilai social secara luas kepada khalayak sasaran sebagai wujud komunikasi dengan masyarakat itu sendiri. Sosialisasi dalam penelitian ini memiliki keterkaitan yang sangat erat dengan peranan public relations yang telah dijelaskan pada sub bab sebelumnya. Berikut ini akan dibahas tentang sosial budaya yang termasuk didalam sosialisasi sekunder.

\section{Sosial Budaya}

Sosial budaya terdiri dari dua kata yaitu Sosial dan Budaya. Sosial berarti segala sesuatu yang berhubungan dengan masyarakat sekitar. Sedangkan budaya berasal dari kata bodhya yang artinya pikiran dan akal budi. Budaya juga diartikan sebagai segala hal yang dibuat manusia berdasarkan pikiran dan akal budinya yang mengandung cinta dan rasa. Jadi, kesimpulannya sosial budaya merupakan segala hal yang diciptakan manusia dengan pikiran dan budinya dalam kehidupan bermasyarakat.

Sosial dalam arti masyarakat atau kemasyarakatan berarti segala sesuatu yang bertalian dengan sistem hidup bersama atau atau hidup bermasyarakat dari orang atau sekelompok orang yang didalamnya sudah tercakup struktur, organisasi, nilainilai Sosial, dan aspirasi hidup serta cara mencapainya (Ranjabar, 2006).

Budaya, kultur atau kebudayaan adalah cara atau sikap hidup manusia dalam berhubungan secara timbal balik dengan alam dan lingkungan hidupnya yang didalamnya sudah tercakup pula segala hasil dari cipta, rasa, karsa, dan karya, baik yang fisik materiil maupun yang psikologis, idiil, dan spiritual (Ranjabar, 2006).

Sosial budaya adalah itu sendiri adalah segala hal yang dicipta oleh manusia dengan pemikiran dan budi nuraninya untuk dan atau dalam kehidupan bermasyarakat. Atau lebih singkatnya manusia membuat sesuatu berdasar budi dan pikirannya yang diperuntukkan dalam kehidupan bermasyarakat.

\section{Model 4 Step}

Urutan yang paling pertama hingga keempat yang harus dilakukan seorang PR dalam kegiatannya menurut Cutlip, Center, dan Broom dalam Morissan, 2006:108-109) sebagai berikut:

\section{Menentukan Masalah (defining the problem)}

Langkah pertama ini meliputi kegiatan untuk meneliti dan mengawasi pengetahuan, pendapat, sikap dan tingkah laku khalayak yaitu pihak-pihak yang berkepentingan atau terpengaruh oleh 
tindakan dan kebijakan organisasi atau perusahaan.

\section{Perencanaan dan Penyusunan Pemrograman (palnning dan programming)}

Masalah yang ditentukan dipada langkah pertama digunakan untuk menyusun program tujuan, tindakan, dan strategi komunikasi. Langkah kedua mencakup tindakan untuk memasukkan temuan yang diperoleh pada langkah pertama ke dalam kebijakan dan program organisasi.

\section{Melakukan Tindakan dan \\ Berkomunikasi (taking action and communicating)}

Langkah ketiga mencakup kegiatan melaksanakan tindakan dan melakukan komunikasi yang sejak awal dirancang untuk mencapai suatu tujuan tertentu.

\section{Evaluasi Program \\ (evaluating the program)}

Langkah terakhir ini mencakup penilaian atau evaluasi atas persiapan, pelaksanaan dan hasil-hasil program. Program dapat dilanjutkan atau dihentikan setelah menjawab pertanyaan: "Bagaimana kita telah melakukannya?" penyesuaian dan perbaikan terhadap tindakan atau komunikasi yang telah dilaksanakan dapat dilakukan berdasarkan umpan balik yang diterima.

\section{METODE PENELITIAN}

Penelitian ini menggunakan pendekatan kualitatif. Penelitian kualitatif merupakan suatu metode berganda dalam fokus, yang melibatkan pendekatan interpretatif dan wajar terhadap setiap pokok permasalahan yang dikajinya (Salim, 2006:34). Dalam penelitian ini, penulis menggunakan konstruktivisme, secara tegas paham ini menyatakan bahwa positisme dan post positivism keliru dalam mengungkap realitas dunia, dan haus ditinggalkan dan digantikan oleh paham bersifat konstruktif (Salim, 2006:71) Metode penelitian menggunakan studi kasus. Studi kasus adalah uraian dan penjelasan komprehensif mengenai berbgai aspek seorang individu, suatu kelompok, suatu organisasi (komunitas), suatu program, atau suatu situasi sosial. Peneliti studi kasus berupaya menelaah sebanyak mungkin data mengenai subjek yang diteliti (Mulyana, 2018:201). Dalam melakukan analisis data ini peneliti melakukan pemeriksaan keabsahan data melalui Triangulasi. Triangulasi adalah teknik pemeriksaan keabsahan data yang memanfaatkan sesuatu yang lain (Moleong, 2010:330)

\section{TEMUAN DAN DISKUSI}

\section{Sosialisasi Empat Pilar Kebangsaan Humas MPR RI Tahun 2019.}

Pendekatan seni budaya menjadi cara yang dipilih Humas MPR RI dalam melaksanakan sosialisasi Empat Pilar Kebangsaan tahun 2019. Hal ini dilakukan supaya sesuai dengan kultur dan karifan lokal yang berlaku di masyarakat kita. Sosialisasi disesuaikan dengan budaya setempat sehingga khalayak lebih mudah menerima dan memahami pesan yang disampaikan.

Temuan penelitian ini didapat dari:

"Sosialisasi Empat Pilar Kebangsaan menjadi salah satu agenda rutin dari Majelis Permusyawaratan Rakyat (MPR) Republik Indonesia (RI) yang selanjutnya dalam penelitian ini disebut MPR RI. Ke empat pilar tersebut yaitu Pancasila, UUD 1945, NKRI dan Bhinneka Tunggal Ika sebagai konsep pokok dalam kehidupan berbangsa dan bernegara. Dalam tatanan berbangsa bernegara perlu diperkuat dengan pilar-pilar sehingga kokoh. Empat pilar adalah penyangga yang kokoh bagi bangsa sehingg rakyat bisa hidup damai, aman dan bersatu membangun bangsa dalam suasana demokratis" (Sekjen MPR Ma'aruf Cahyono) 
Hasil temuan diperkuat dengan pernyataan:

"Dalam penelitian ini MPR RI melakukan sosialisasi dengan metode atau cara yang lebih kultural yang disesuaikan dengan budaya setempat. Di Jawa sosialiasasi dilakukan dengan pagelaran wayang dengan maksud untuk merawat kearifan lokal. Di Sumatera, juga berbeda, di Sumatera Utara misalnya dengan tari Tor-Tor, di daerah yang sukunya melayu menggunakan pantun, sampai ke Indonesia bagian Timur. dalam sosialisasi empat pilar kebangsaan menggunakan metode sosial budaya karena dalam seni budaya kita (nasional) terkandung nilai filosofis berisi tuntunan dan panutan dan tuntunan selain sebagai hiburan" (Sebagaimana dikatakan Kepala Biro Humas MPR RI Siti Fauziah wawancara dengan peneliti Oktober 2019).

Hal tersebut didukung oleh Humas Pemberitaan MPR RI dalam melakukan sosialisasi Empat Pilar MPR RI Tahun 2019 ini, melalui kegiatan seni budaya. Dari seni budaya tersebut, Humas MPR RI memahami terlebih dahulu wilayah atau daerah mana yang ingin dimanfaatkan ciri khas budayanya sehingga dapat di akulturasikan dengan unsur Empat Pilar. Dengan begitu, Humas MPR RI dapat melakukan kegiatan sosialisasi Empat Pilar dan pubik atau masyarakat yang mengikutinya dapat dengan mudah menangkap pemahaman akan Empat Pilar tersebut. Hal berikut dijelaskan oleh Bapak Budi Muliawan:

"Humas MPR dalam melaksanakan kegiatan sosialisasi Empat pilar MPR hanya melalui kegiatan seni budaya,,

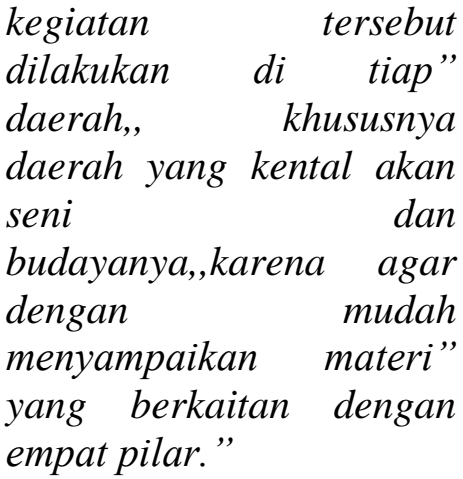

Hambatan Sosialisasi Empat Pilar Kebangsaan Humas MPR RI Tahun 2019.

Dalam mensosialisasikan Empat Pilar KebangsaanTahun 2019, adapun hambatan yang dialami terkait akses dan jarak dari segi wilayah. Seperti pernyataan Ibu Siti Fauziah yang mengatakan bahwa:

"Kelemahannya dalam melakukan sosialisasi Empat Pilar dalam bentuk seni budaya ini biasanya kita itu kedaerah-daerah pelosok atau terpencil, itupun sudah memakan energy kita yang banyak. Hambatannya ya seperti tadi kedaerah-daerah terpencil atau pelosok yang susah banget ditempuh dan memakan waktu yang cukup lama”.

Selain itu, hambatan yang terjadi dalam melakukan kegiatan sosialisasi Empat Pilar MPR RI Tahun 2019 ini ialah masalah segi wilayah atau daerah terpencil. Yang dimana mungkin terjadi kesulitan dalam jangkau perjalanan menuju tempat tersebut dan masalah internal administrasi yang lambat mengeluarkan dana untuk acara kegiatan sosialisasi Empat Pilar yang dilakukan di suatu daerah. Karena ketika ada hambatan di bagian administrasi, maka kegiatan sosialisasi ini tidak akan berjalan dengan lancar dan tidak sesuai 
harapan. Seperti yang dikatakan oleh Bapak Budi Muliawan bahwa:

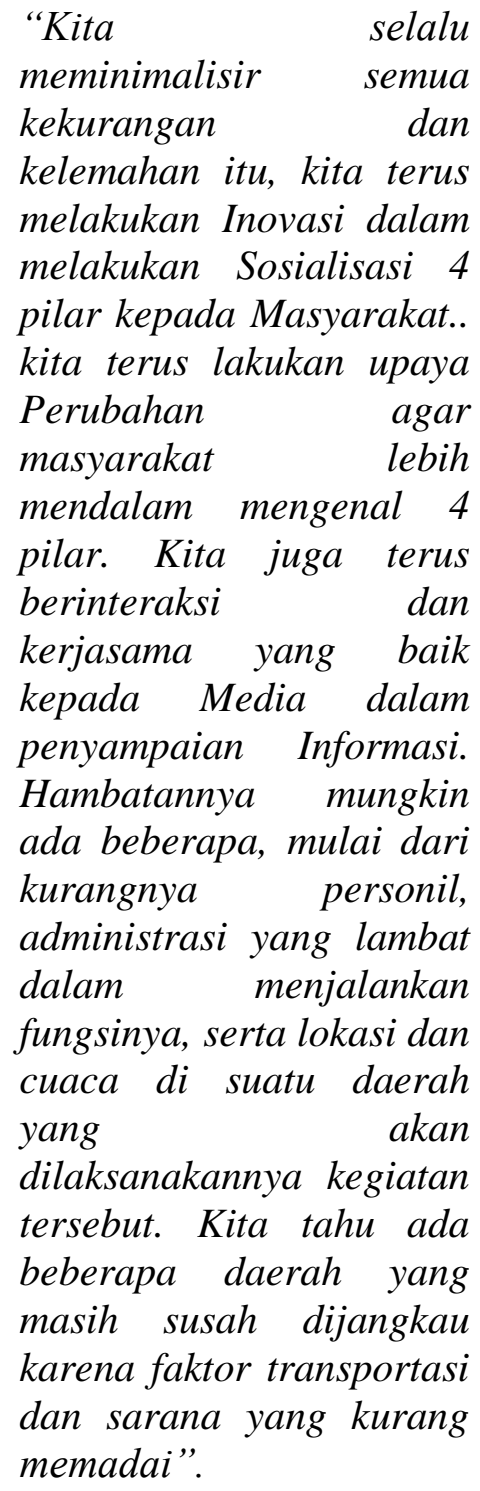

\section{Strategi Sosialisasi Empat Pilar Kebangsaan Humas MPR RI Tahun 2019}

Strategi Humas MPR RI Bagian Pemberitaan dalam mensosialisasikan Empat Pilar Tahun 2019, yaitu terkait dalam tugasnya MPR RI yang dimana tertulis dan sudah paten serta tertera di Undang-Undang yang dimana salah satu tugasnya adalah mensosialisasikan Empat Pilar. Dari situlah jelas bahwa kegiatan sosialisasi ini sudah tertera dan tertulis serta harus dilaksanakan. Jadi ketika ada kegiatan sosialisasi Empat Pilar, masyarakat tahu bahwa ini adalah acara atau kegiatannya MPR RI. Ibu Siti Fauziah mengatakan bahwa:

"Jadi, yang
melatarbelakangi
dilakukannya sosialisasi
Empat Pilar (Pancasila,
UUD 1945, NKRI dan
Bhinneka Tunggal Ika) ini
adalah sesuai amanat
Pasal 5 Huruf a dan huruf
bUU Nomor 17 Tahun
2014 sebagaimana telah
diubah dengan UU Nomor
42 Tahun 2014 tentang
MPR yang salah satu
tugas nya adalah
mensosialisasikan Empat
Pilar atau Ketetapan MPR
(Pancasila, UUD NRI
1945, NKRI dan Bhinneka
Tunggal Ika kepada
seluruh masyarakat
diseluruh wilayah tanah
air. Jadi dasar hukumnya
sudah jelas sesuai dengan
UUD 1945".

Salah satu tugas Humas dalam melaksanakan suatu kegiatan adalah melakukan riset terlebih dahulu. Untuk Humas MPR RI Bagian Pemberitaan dalam mensosialisasikan Empat Pilar Tahun 2019, kegiatan sosialisasi sudah direncanakan dan dibuat oleh Biro Persidangan atau Sosialisasi. Humas Pemberitaan MPR RI ini juga ikut andil dalam melaksanakan tugasnya sebagai penyebarluasan Empat Pilar tersebut. Ibu Siti Fauziah mengatakan bahwa:

"Jadi, yang Riset itu bukan dari Humas karena sudah ada tugas masing masing dari setiap Biro yaitu Biro Sosialisasi atau Biro Persidangan yang mempunyai kewenangan untuk melakukan Sosialisasi, tetapi di MPR ini semua Unit memiliki 
bagian mensosialisasikan jadi dibagi-bagi lagi”.

Selain itu, strategi yang dilakukan oleh Humas MPR RI dilihat dari segi segmentasi sesuai wilayah maupun daerah yang dikemas dalam bentuk Budaya. Dari situ, Humas MPR RI mengemas unsur Empat Pilar ini yang dikaitkan kedalam segi seni budaya yang tergantung dari segmentasi atau target sasaran khalayak yang ditujunya didalam wilayah atau daerah tersebut. Jadi, dari segi itulah strategi dan penyampaian pesan Humas MPR RI terkait pemahaman Empat Pilar ini dinyatakan efektif sehingga berjalan dengan baik sesuai target sasaran dan segmentasi wilayah. Ibu Siti Fauziah mengatakan bahwa :

"Jadi macam-macam yaa, Strategi nya langsung ke sasaran yang kita tuju atau to the point. Misalnya kalau yang dilakukan Humas itu melalui bentuk seni budaya, dari situ kita pasti

mengkomunikasikannya

terlebih dahulu melalui daerahnya dan memahami kebudayaan di daerah yang akan kita lakukan Sosialisasi Empat Pilar tersebut dan memahami terlebih dahulu seperti apakah kebudayaan didaerah tersebut sudah mulai punah karena terkikis oleh zaman yang modern ini atau tidak, dari situlah strategi komunikasi melalui budaya yang perlu kita angkat dan tergantung segmentasi nya khalayak itu sendiri".

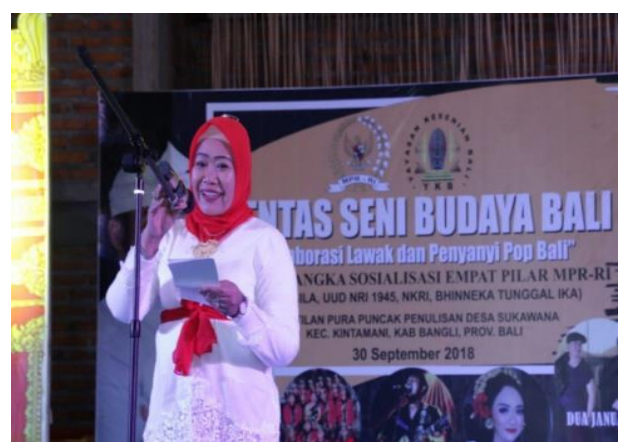

Gambar 1.

Sosialisasi Dengan Sosial Budaya (sumber: Humas MPR RI)

Adapun hal lainnya, dalam merencanakan Strategi Komunikasi Humas MPR RI Tahun 2019 ini adalah membangun kerjasama dan relationship atau media partner dari Humas MPR RI kepada media. Media disini sangat berperan penting terhadap penyebarluasan pesanpesan komunikasi ataupun kegiatan yang dilakukan MPR RI khususnya kegiatan sosialisasi Empat Pilar MPR RI ini. Dengan begitu, media disini ikut andil sehingga implikasi dari sosialisasisosialisasi yang Humas MPR RI lakukan berjalan dengan lancer dan efektif. Bapak Budi Muliawan mengatakan bahwa:

"Strategi Komunikasi
yang kita lakukan adalah
bekerja sama dengan
Media, baik dari Media
Cetak, Visual, Maupun
Media Online. Bagaimana
pun Peran Media di sini
sangat Strategis dalam
memberikan Informasi
kepada masyarakat dan
sangatlah berperan dalam
penyampaian pesan-pesan
yang kita sampaikan
kepada Masyarakat".

Sosialisasi Empat Pilar ini, merupakan salah satu tugas yang harus dilaksanakan oleh MPR RI. Dengan begitu terkait didalamnya adalah seluruh Biro MPR RI yang terkait didalamnya sehingga tidak hanya Humas Pemberitaan saja. Tetapi, Humas MPR RI Bagian Pemberitaan melaksanakan fungsinya yaitu untuk 
menyebarluaskan berita maupun kegiatan sosialisasi Empat Pilar tersebut. Amirrudin mengatakan bahwa:

"Terkait sosialisasi Empat

Pilar, itukan tugas dan wewenang nya itu sebenarnya bukan tertuju pada level Humas saja tetapi kepada seluruh atau level pimpinan. Kami selaku dari Sekretariat khususnya Humas MPR RI itu berkewajiban untuk mendukung. Dalam hal ini, Humas MPR RI ini ada bagian masingmasing. Contohnya di bagian Humas Pemberitaan, jadi ketika Pimpinan, Anggota bahkan yang lainnya melakukan Kegiatan Sosialisasi Empat Pilar, kita dukung. Untuk memberitakan ke semua khalayak / masyarakat supaya masyarakat tahu, ketika tugas dan wewenang dari MPR RI ini sudah dijalankan oleh kita. Maka dari itu, dukungan dari Pemberitaan untuk sosialisasi Empat Pilar itu'”.

Didalam setiap melakukan kegiatan Sosialisasi Empat Pilar, Humas MPR RI Bagian Pemberitaan melakukan evaluasi setelah kegiatan itu selesai. Kegiatan itu buat Humas MPR RI sangatlah penting demi patokan agar kegiatan-kegiatan sosialisasi Empat Pilar MPR RI lainnya itu lebih baik lagi dan lebih sempurna lagi. Karena dengan adanya evaluasi, kegiatan Humas MPR RI bisa terekap misalkan apasaja yang kurang memadai atau apa yang menjadi hambatan-hambatan yang terjadi ketika pelaksanaan kegiatan sosialisasi Empat
Pilar tersebut. Ibu Siti Fauziah mengatakan bahwa:

"Setiap melakukan
kegiatan, kita pasti
mengadakan Evaluasi.
Jadi sebagai koreksi kita
juga bahwa ketika
kegiatan yang sudang
berlangsung ada yang
kurang, itu pasti akan
menjadi patokan kita
kedepannya agar kegiatan
sosialisasi Empat Pilar
tersebut ini tidakada yang
kurang-kurang lagi dan
agar lebih baik lagi".

Hal evaluasi dalam kegiatan Sosialisasi Empat Pilar Kebangsaan Humas MPR RI tersebut juga didukung oleh Bagian Pemberitaan oleh Budi Muliawan yang mengatakan bahwa:

"Selalu kita lakukan
evaluasi,setiap kegiatan
yang dilakukan pasti ada
evaluasinya, untuk
mengurangi dan
meminimalisir berbagai
resiko yang ada".

\section{Pembahasan}

Berdasarkan hasil pengamatan dan wawancara mendalam yang telah peneliti lakukan dengan narasumber, maka peneliti menemukan bahwa salah satu fungsi Humas/PR adalah menjalin komunikasi dan relasi dengan publikpublik organisasi. Dampak dari terwujudnya fungsi ini adalah pencapaian tujuan organisasi. Tujuan organisasi itu dibantu pencapaiannya melalui kegiatan PR dengan meningkatkan, menjaga atau memperbaiki prestise organisasi, mendeteksi dan menangani isu-isu yang berkembang, dan mengatasi kesalahpahaman dan parasangka.

Pembahasan terkait Sosialisasi Empat Pilar Kebangsaan Humas MPR RI 
tahun 2019 dapat dijelaskan dengan Model Four Steps sebagai berikut:

\section{Menentukan Masalah}

(defining the problem)

Sosialisasi Empat Pilar Kebangsaan Humas MPR RI tahun 2019 adalah hasil evaluasi dari tahun sebelumnya. Humas menilai sosialiasasi perlu dimaksimalkan sehingga tujuan dapat tercapai dengan baik. Dala tahap ini pimpinan dan Humas MPR RI menentukan masalah terkait sosialisasi ditemukan bahwa prioritas utama harus dilaksanakan di daerah terpencil dan daerah perbatasan sehingga nilai-nilai nasionalisme dapat tumbuh bagi masyarakat yang hidup dan ditinggal di daerah tersebut. Perlu metode baru untuk melakukan sosialisasi yang selama ini dianggap monoon maka perlu pembenahan dan perbaikan.

Perencanaan dan Penyusunan

Pemrograman (palnning dan programming)

Program sosialisasi disusun dengan membuat skala prioritas ke daeerah terpencil dan daerah perbatasan untuk satu tahun masa kerja. Kemudian dibuat anggaran dan penentuan personil yang akan berangkat untuk melakukan sosialisasi sesuai dengan tema yang sudah ditentukan oleh pimpinan MPR RI. Melibatkan partisipasi masyarakat dan berbagai kelompok sehingga terbangun kerjasama dalam melaksanakan program tersebut.

\section{Melakukan Tindakan dan \\ Berkomunikasi (taking action and communicating)}

Pada tahap ini pihak Humas MPR RI melakukan kordinasi dengan berbagai kelompok kepentingan, baik kelompok formal maupun kelompok informal. Pihak Humas berkordinasi dengan sekolah, kampus, tokoh desa, tokoh masyarakat, tokoh adat, Polri dan TNI. Kordinasi juga dilakukan dengan pihak ormas dan media lokal guna mendukung acara sosialisasi tersbut. Sosialisasi dilakukan dengan pendekatan sosial budaya dengan kegiatan seni budaya, berupa lomba, pagelaran dan seremoni. Kegiatan sosialisasi disesuakan dengan kultur daerah setempat, sehingga mampu mengangkat potensi daerah juga kearifan lokal sehingga muncul kerjasama dan ketergantungan yang saling menguntungkan. Ada upaya pelibatan masyarakat lokal sehingga mereka tidak menjadi penonton tetapi juga jadi pelaku sosialisasi tersebut.

\section{Evaluasi Program (evaluating the program).}

Pada tahap ini pimpinan dan Humas MPR RI membuat alat ukur atas keberlangsungan acara tersebut sehingga dapat dinilai keberhasilan dan kekuarangannya. Pada tahap ini pihak Humas MPR bisa menggunakan penilaian atau alat ukur dari pemberitaan media baik nasional maupun lokal, meminta masukan pada pihak terkait, membuat FGD dan evaluasi-evaluasi lain yang relevan dengan kepentingan dan keperluan organisasi. Tetapi prinsipnya setiap selesai sosialisasi pihak Humas selalu mengadakan evaluasi berkala.

\section{SIMPULAN}

Sosialisasi Empat Pilar Kebangsaan Humas MPR RI 2019 ini dapat disimpulkan sesuai dengan tujuan penelitian sebagai berikut: sosialisasi dilakukan dengan pendekatan sosial budaya setempat sehingga mudah dipahami sekaligus mengangkat kearifan lokal. Sosialisasi dengan seni budaya setempat juga penuh filosofi yang sejalan dengan Pancasila sebagai dasar negara.

Hambatan dalam sosialisasi Empat Pilar Kebangsaan Humas MPR RI dalam Tahun 2019 ini yaitu faktor Internal dari MPR RI, berupa kurangnya personil, administrasi yang lambat serta akses dan jarak dengan lokasi yang dituju khususnya daerah terpencil dan daerah perbatasan.

Sosialasasi menjadi tanggungjawab Biro Humas MPR RI dengan melaksanakan tahapan menentukan Masalah (defining 
the problem), Perencanaan dan Penyusunan Pemrograman (palnning dan programming), Melakukan Tindakan dan Berkomunikasi (taking action and communicating), Evaluasi Program (evaluating the program).

Perlu ada penelitian lanjutan untuk menyempurnakan penelitian ini sehingga hasilnya dapat dipergunakan utuk kepentingan yang lebih besar.

\section{DAFTAR PUSTAKA}

Cangara, Hafied. 2017. Perencanaan \& Strategi Komunikasi. Edisi Revisi. Jakarta: PT. Raja Grafindo Persada. Cutlip, Scoot M., Allen H. Center, dan Glen M. Broom. 2011. Effective Public Relations, Edisi Kesembilan. Jakarta: Kencana.

Jefkins, Frank \& Daniel Yadin. 2003.

Public Relations. Jakarta: Erlangga.

Hasan, Erlina. 2005. Komunikasi Pemerintahan. Bandung: Rafika Aditama

Lawang, Robert. 2004. Pengantar

Sosiologi. Jakarta: Modul Universitas Terbuka.

Moleong, J. Lexy, 2010. Metodologi Penelitian Kualitatif. PT. Remaja Rosdakarya, Bandung.

Morissan. 2006. Manajemen Public Relations. Strategi Menjadi Humas
Profesional. Jakarta: Kencana

Prenada Media Grup

Mulyana, Deddy. 2018. Metode

Penelitian Kualitatif. Cetakan

Kedelapan. Bandung: Remaja

Rosdakarya.

Ranjabar, Jacobus. 2006. Sistem Sosial Budaya Indonesia Suatu

Pengantar. Bandung: Ghalia Indonesia.

Ruslan, Rosady. 2008. Manajemen Public Relatoins \& Media Komunikasi. Jakarta: PT. Rajagrafindo Persada.

Salim, Agus. 2006. Teori dan Paradigma Penelitian Sosial. Yogyakarta: Tiara wacana.

Iriantara, Yosal. 2006. Public Relations Writing. Pendekatan Teoritis dan Praktis. Bandung: Simbiosa Rekatama Media

Rezeky, Rialdo dan Saefullah, Muhammad. Strategi Humas Partai Gerindra dalam Membangun Citra Partai pada Pemilu 2014. Journal of Communication (Nyimak), Vol. 1, No. 1, Juni 2017. 